\title{
Role and Modulation of NK Cells in Multiple Myeloma
}

\author{
Marie Thérèse Rubio ${ }^{1, *}$, Adèle Dhuyser ${ }^{2}$ and Stéphanie Nguyen ${ }^{3}$ \\ 1 Service d'Hématologie, Hopital Brabois, CHRU Nancy, CNRS UMR 7563 IMoPa, Biopole de l'Université de \\ Lorraine, 54500 Vandoeuvre-les-Nancy, France \\ 2 Laboratoire HLA, Hopital Brabois, CHRU Nancy, CNRS UMR 7563 IMoPa, Biopole de l'Université de \\ Lorraine, 54500 Vandoeuvre-les-Nancy, France; adele.dhuyser@gmail.com \\ 3 Service d'Hématologie Clinique, Groupe Hospitalier Pitié-Salpêtrière APHP.6, Pavillon Georges Heuyer and \\ INSERM CNRS 1135, NK and T Cell Immunity, Virus and Cancer, Centre d'Immunologie et des Pathologies \\ Infectieuses (CIMI), Sorbonne Université, 47-83 Bd de l'Hôpital, CEDEX 13, 75651 Paris, France; \\ stephanie.nguyen-quoc@aphp.fr \\ * Correspondence: m.rubio@chru-nancy.fr; Tel.: +33-385-153-282; Fax: +33-385-153-558
}

Citation: Rubio, M.T.; Dhuyser, A.; Nguyen, $S$. Role and Modulation of NK Cells in Multiple Myeloma.

Hemato 2021, 2, 167-181.

https: / / doi.org/10.3390/

hemato2020010

Academic Editor: Nicolaus Kröger

Received: 5 March 2021

Accepted: 28 March 2021

Published: 2 April 2021

Publisher's Note: MDPI stays neutral with regard to jurisdictional claims in published maps and institutional affiliations.

Copyright: (c) 2021 by the authors. Licensee MDPI, Basel, Switzerland. This article is an open access article distributed under the terms and conditions of the Creative Commons Attribution (CC BY) license (https:// creativecommons.org/licenses/by/ $4.0 /)$.

\begin{abstract}
Myeloma tumor cells are particularly dependent on their microenvironment and sensitive to cellular antitumor immune response, including natural killer (NK) cells. These later are essential innate lymphocytes implicated in the control of viral infections and cancers. Their cytotoxic activity is regulated by a balance between activating and inhibitory signals resulting from the complex interaction of surface receptors and their respective ligands. Myeloma disease evolution is associated with a progressive alteration of NK cell number, phenotype and cytotoxic functions. We review here the different therapeutic approaches that could restore or enhance NK cell functions in multiple myeloma. First, conventional treatments (immunomodulatory drugs-IMids and proteasome inhibitors) can enhance NK killing of tumor cells by modulating the expression of NK receptors and their corresponding ligands on NK and myeloma cells, respectively. Because of their ability to kill by antibody-dependent cell cytotoxicity, NK cells are important effectors involved in the efficacy of anti-myeloma monoclonal antibodies targeting the tumor antigens CD38, CS1 or BCMA. These complementary mechanisms support the more recent therapeutic combination of IMids or proteasome inhibitors to monoclonal antibodies. We finally discuss the ongoing development of new NK cell-based immunotherapies, such as ex vivo expanded killer cell immunoglobulin-like receptors (KIR)-mismatched NK cells, chimeric antigen receptors (CAR)-NK cells, check point and KIR inhibitors.
\end{abstract}

Keywords: myeloma; NK cells; immunomodulation; cell therapy; immunotherapy

\section{Introduction}

Multiple myeloma (MM) is a mature B-cell hematologic neoplasia characterized by the clonal proliferation of plasma cells in the bone marrow [1]. It evolves in a multistep way from the pre-malignant monoclonal gammopathy of undetermined significance (MGUS) through a phase of asymptomatic smoldering myeloma until the symptomatic phase of MM, often presenting with bone lesions, hypercalcemia, renal failure and anemia [2]. Cytogenetic and epigenetic events both contribute to the progression towards a more active disease and the failure of immune surveillance with a progressive impairment of both innate and adaptive antitumor immune responses [3]. Natural killer (NK) cells are innate lymphoid cells that have been shown to play a major role in the anti-myeloma immune response [4]. Despite the development of multiple treatment strategies, including chemotherapy, proteasome inhibitors, immunomodulatory drugs, monoclonal antibodies and hematopoietic stem cell transplantation, MM remains incurable. Many patients evolve to a relapse and refractory $(R / R)$ MM. One goal of the new treatment strategies in MM is to restore an effective immune response against myeloma cells. This review provides 
an overview of NK cells' role in the development and treatment of MM and discusses potentially new NK-based immunotherapies that may improve clinical outcomes.

\section{Biology of NK Cells}

NK cells are innate lymphoid cells representing the first effectors against malignant or virus-infected cells. By contrast with T cells, NK cells can kill without prior sensitization or recognition of presented antigens [5]. Human NK cells are defined as CD3 ${ }^{\text {neg }} \mathrm{CD} 6^{+}$and represent 5 to $15 \%$ of peripheral blood lymphocytes among which, two subtypes have been phenotypically and functionally described: the CD56 ${ }^{\mathrm{dim}}$ and CD56 $6^{\text {bright }}$ cells. CD56 ${ }^{\mathrm{dim}}$ cells are characterized by cytotoxic activities, while CD56 ${ }^{\text {bright }}$ cells mainly produce cytokines, such as IFN- $\gamma$ and TNF- $\alpha$ and are implicated in immune regulation [6]. They also can express CD16 (FC $\gamma$ RIIIa), which binds human IgG through their Fc fragment, allowing antibody-dependent cellular cytotoxicity (ADCC) to occur [5]. While the majority of circulating NK cells in the peripheral blood are CD16 $6^{\text {bright }} / \mathrm{CD} 56^{\text {dim }}$ with high cytotoxic capacities and low proliferative response to IL-2, NK cells localized in secondary lymphoid tissues or inflammation sites is CD16 $\mathrm{dim} / \mathrm{neg} / \mathrm{CD} 56^{\mathrm{bright}}$, highly express IL2-R $\alpha$ and have high proliferative capacities, but lower cytotoxicity [5]. NK cell kills their target cells by releasing the content of their lytic granules (perforin, granzyme), by expressing death molecules (Fas-L, TRAIL) at their surface and by secreting INF- $\gamma$ and TNF- $\alpha$; all of them induce apoptosis through caspase-dependent and independent pathways [7].

NK cell function depends on integrating signals from the interaction between activating and inhibiting surface receptors and their respective ligands. The initial description of the "missing-self" mechanism of cell death (i.e., lack of expression of HLA class I molecules on target cells spotted by NK inhibitory receptors) has been since revisited. Regulation of NK function is recognized to be more complex and dependent on the relative balance between inhibitory and activating signals induced by the engagement of inhibitory versus activating receptors according to the presence or absence of cognate ligands on target cells [5].

Inhibitory receptors include killer cell immunoglobulin-like receptors (KIR) and nonKIR inhibitory receptors. Among the inhibitory KIRs, three are critical for NK cell function: KIR2DL1, KIR2DL2/3 and KIR3DL1, specific for HLA class I molecules (HLA-Cw antigens belonging to the HLA C2 and HLA C1 families, and HLA-Bw4 antigens, respectively). Identified non-KIR inhibitory receptors so far are the C-type lectin-like receptors CD94/NKG2A heterodimer (CD159a), specific for HLA-E; ILT2 (LILRB1, CD85) recognizing various class I antigens; NKR-P1A (CD161) recognizing the lectin-like transcript 1 (LLT1); and the carcinoembryonic antigen-related cell adhesion molecule 1 (CEACAM-1, CD66a) specific for CD66 ligand [8]. In addition, NK cells can express the checkpoint inhibitors, such as programmed cell death protein-1 (PD-1), T-cell immunoglobulin and mucin containing protein-3 (TIM-3) and T cell immunoreceptor with Ig and ITIM domains (TIGIT). They can be inhibited by interaction with the corresponding ligands often expressed on tumor cells: PD-L1 or PD-L2 for PD-1; HMGB1 (high mobility group B1 protein), CEACAM-1, phosphatidylserine or Galectin-9 for TIM-3; PVR (poliovirus receptor, CD155) and nectin-2 (CD112) for TIGIT [9] (Figure 1). 
Ligands

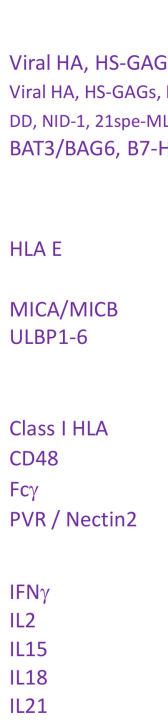

ACTIVATING RECEPTORS

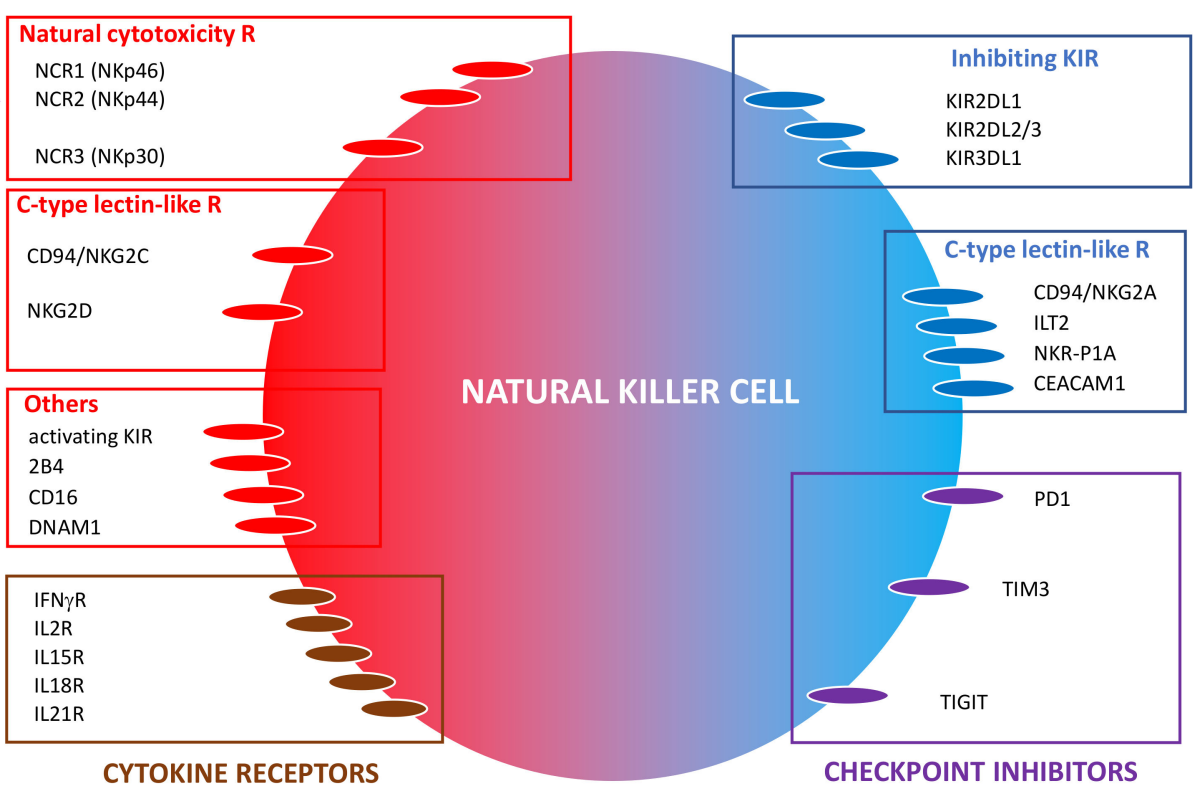

Ligands

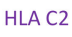

HLA C1

HLA BW4

HLAE

Class I HLA

LLT1

CD66-L

PDL1/PDL2

HMGB

CEACAM1

Phosphatidylserin

Galactin-9

PVR

Nectin 2

\section{ACTIVATING INTERACTIONS}

Figure 1. Natural killer (NK) cell inhibitory and activating receptors and ligands.

NK cells also express activating receptors. In addition to CD16 (Fc $\gamma$ RIIIa), they can express natural cytotoxicity receptors NCRs: NKP46 (NCR1, CD335); NKp44 (NCR2, CD336) and NKp30 (NCR3, CD337), which ligands are partially characterized. The main ligands are derived from infectious agents (mainly viral hemagglutinins), cell-membrane, or extracellular matrix-derived proteins, such as heparan sulfate (HS) glycosaminoglycans (GAGs) or molecules expressed on tumor cells [10]. In the context of cancers, NKp46 can bind HS-GAGs, NKp44 can be activated by HS-proteoglycans (HSPGs), platelet-derived growth factor-DD (PDGF-DD), nidogen-1 (NID-1), an isoform of mixed-lineage leukemia protein-5 (21spe-MLL5) and Galectin 3 (Gla-3), while NKp30 recognizes HLA-B associated transcript 3/Bcl-2 associated pathogens 6 (BAT3/BAG6) and B7-H6 [10]. Other activating receptors include C-type lectin-like receptors, such as NKG2D (CD314) and the heterodimer CD94/NKG2C (CD159c) recognizing stress-induced cell surface ligands, such as the MHC-related ligands A and B (MICA, MICB) and the UL16-binding proteins 1-6 (ULBP1-6) for the first one and HLA-E for the later. Activating receptors include SLAMrelated 2B4 (CD244), which engages CD48 and the DNAX accessory molecule-1 (DNAM1, CD226). recognizing PVR (polio virus receptor or CD155) and nectin-2 (CD112). Some KIRs recognizing classical and non-classical class I HLA molecules can be activating [8] (Figure 1).

NK cells express receptors for several cytokines (IFN- $\gamma$, IL-2, IL-15, IL-18, IL-21) involved in their survival, differentiation, activation and proliferation (Figure 1). IL-2 induces NK proliferation and increases NKG2D and NKp44 expression, while IL-15 drives NK cell differentiation and proliferation. The combination of IL-2 and IL-15 improves NK cell viability in vitro. IL-18 stimulates IFN- $\gamma$ production and provides costimulatory activation, while IL-21 enhances NK cells' maturation [11]. Upon activation and Fc binding, NK cells express CD137 (4-1BB), and anti-CD157 mAbs enhance their cytotoxic properties [12].

\section{NK Cells as Immunotherapeutic Effectors: Lessons from Allogeneic HSCT}

In an autologous setting and the absence of stress, NK cells fail to kill autologous tumor cells as they are inhibited by the interaction between NK-inhibitory surface receptors (mainly KIR and CD94/NKG2A) and self HLA-class I ligands. 
The proof of concept that NK cells may have an immunotherapeutic action against malignant cells first came from allogeneic hematopoietic stem cell (HSC) transplantation performed with haplo-HLA-mismatched donors (haplo-HSCT). The Perugia's group developed a platform of haplo-HSCT combining the use of a myeloablative conditioning regimen and the administration of a T-cell depleted megadose of $\mathrm{CD}_{4} 4^{+}$selected HSCs allowing the engraftment of haplo-mismatched HSC with the absence of acute or chronic graft-versus-host disease (GVHD) [13]. This ex vivo T cell-depleted haplo-HSCT platform represented an ideal in vivo model to investigate the role of NK cells in the absence of confounding factors, such as alloreactive $\mathrm{T}$ cells or immunosuppressive drugs. In such an environment, donor KIR-mismatched NK cell clones expand after transplantation and have the capacity to kill recipient HSC, antigen-presenting cells (APC) and leukemic cells, thus facilitating engraftment and the graft-versus-leukemia effect without GVHD [14,15]. Other studies from the same group demonstrated that NK alloreactivity could be predicted by the "KIR-ligand mismatch" model based on the principle that when the donor carry at least one KIR ligand (i.e., HLA CLASS I Bw4, C1 or C2) absent in the transplant recipient, donor NK cells, supposed to express the corresponding inhibitory KIRs, will kill recipient cells missing the HLA Class I allele [16]. The role of alloreactive KIR-mismatched NK cells in the anti-leukemic effect has been confirmed by other models of in vitro T-cell depleted haplo-HSCT [17-19].

Because KIR and HLA genes are localized in distinct chromosomes (chromosome 19q13.4 and 6p21, respectively) and thus segregate independently, an HLA matched donorrecipient pair can be KIR-mismatched. More recent studies exploring NK alloreactivity on transplant outcomes have then been performed in T-cell repleted haploidentical, mismatched unrelated, cord-blood, but also in matched unrelated HSCT (MUD). In allo-HSCT performed with MUD and mismatched MUD, the group of Kroger showed a reduction of relapse in MM patients transplanted with a KIR-ligand-mismatched donor [20]. However, in these settings, the role of the KIR-ligand mismatches has been a matter of debate, with some studies showing no advantage or even a negative impact [21-25].

The development of KIR genotyping, considering both inhibitory and activating KIRs, has provided better predictive tools. Cooley et al. demonstrated that the assigned presence of a donor KIR genotype enriched in activating KIRs (Bx haplotype) was associated with better disease-free survival in AML transplanted with unrelated donors [26,27]. The combination of both donor KIR genotyping and donor/recipient HLA typing seems to represent the best approach to predict the potential impact of NK cells on post-transplant outcomes [28]. Impaired immune NK cell reconstitution after haplo-HSCT may also contribute to the contradictory clinical impact of NK cell alloreactivity reported so far [24,29].

Despite some controversial reports due to the use of distinct predictive models and to an imperfect understanding of NK cell interactions and regulation, it is acknowledged that NK cells play a role in the control of hematological malignancies.

\section{NK Cells in MM}

Several studies have pointed to the crucial role of NK cells in the control of MM. First, human plasma cells have been shown to be sensitive to NK cell killing from healthy donors [30]. Indeed, in MGUS and early-stage MM, plasma cells can be recognized and killed by NK cells through their expression of ligands for NK-activating receptors, such as the NKG2D ligands MICA and MICB, NKp30 ligand B7-H6, and DNAM-1 ligands nectin-2 and PVR, in combination with the reduced engagement of inhibitory KIR due to low HLA class I expression on myeloma cells [31,32].

However, both quantitative and qualitative alterations of NK cells have been reported in the progression from MGUS to MM. Compared to healthy individuals, a number of peripheral blood (PB) NK cells seem to decrease from the higher or normal value at the stage of MGUS or early-stage untreated MM to reduced numbers in advanced-stage untreated patients [33]. Functional studies have shown that NK remains cytotoxic in MGUS patients, while they may lose their cytotoxic capacities in advanced MM [34,35]. Decreased cyto- 
toxicity is associated with reduced expression of activating receptors like CD16, NKG2D, NCRs, 2B4 and DNAM-1 in PB and/or BM NK cells of MM patients [32,36,37] and increase expression of the inhibitory receptors KIR2DL1 and PD1 [38,39]. After autologous HSCT, a higher expression of the activating receptor KIR2DS4 and decreased expression of the inhibitory CD94/NKG2A has been observed in patients with detectable minimal residual disease (MRD), analyzed by flow cytometry, compared with those with negative MRD [40].

Alterations of NK cell phenotype and functions are explained by the transformation of myeloma tumor cells and their microenvironment during disease evolution [41]. Many cellular and soluble factors have been involved in the alteration of NK cell phenotype and functions during the progression of the disease. Among those, TGF- $\beta$ produced in MM by plasma cells [42], regulatory T cells (Tregs) [43] or potentially by myeloid-derived suppressive cells (MDSCs) [44] has been described to downregulate NK-activating receptors and to impair NK functions [45,46]. Increased levels of IL-6 and IL-10 are also observed in MM $[47,48]$. These cytokines act as growth factors for plasma cells and promote the development of NK-resistant tumor phenotype by inhibiting NK cell activity [49,50]. Prostaglandin E2 (PGE2), produced in cultures of BM from MM patients [51], may inhibit activating signals transduced by NCRs, NKG2D and CD16 [52]. Indoleamine 2,3-deoxygenase (IDO) produced by stromal dendritic cells when they interact with CD28 expressed on plasma cells can impair NK-mediated lysis by inhibiting the expression of NKp46 and NKG2D [53,54].

In parallel, myeloma plasma cells progressively develop different strategies to escape NK cell killing. High levels of expression of HLA class I and of HLA-E (ligands for inhibitory KIRs and CD94/NKG2A, respectively) are observed in tumor cells from advanced MM patients, which was associated with reduced degranulation of NK cells in vitro [55]. Another way for MM to escape NK cell lysis is to cleave the surface expression of the NKG2D-ligands MICA and MICB [56]. Indeed, soluble MIC ligands induce the internalization of NKG2D and NCRs and promote the accumulation of MDSCs and immunosuppressive macrophages $[57,58]$. Plasma cells can escape immune lymphocytes by expressing PDL-1 [38]. Finally, myeloma cells can alter the chemokine microenvironment to promote the migration of NK cells (expressing CXCR3 or CXCR4) outside the BM, consequently to the upregulation of serum levels of the CXCR3-ligand CXCL10 and the downregulated expression of the CXCR4-ligand CXCL12 in the BM [59].

\section{Therapeutic Modulation of NK Cells in MM}

Most of the therapeutic agents used in the treatment of MM either modulate or require NK cell functions (Figure 2). 


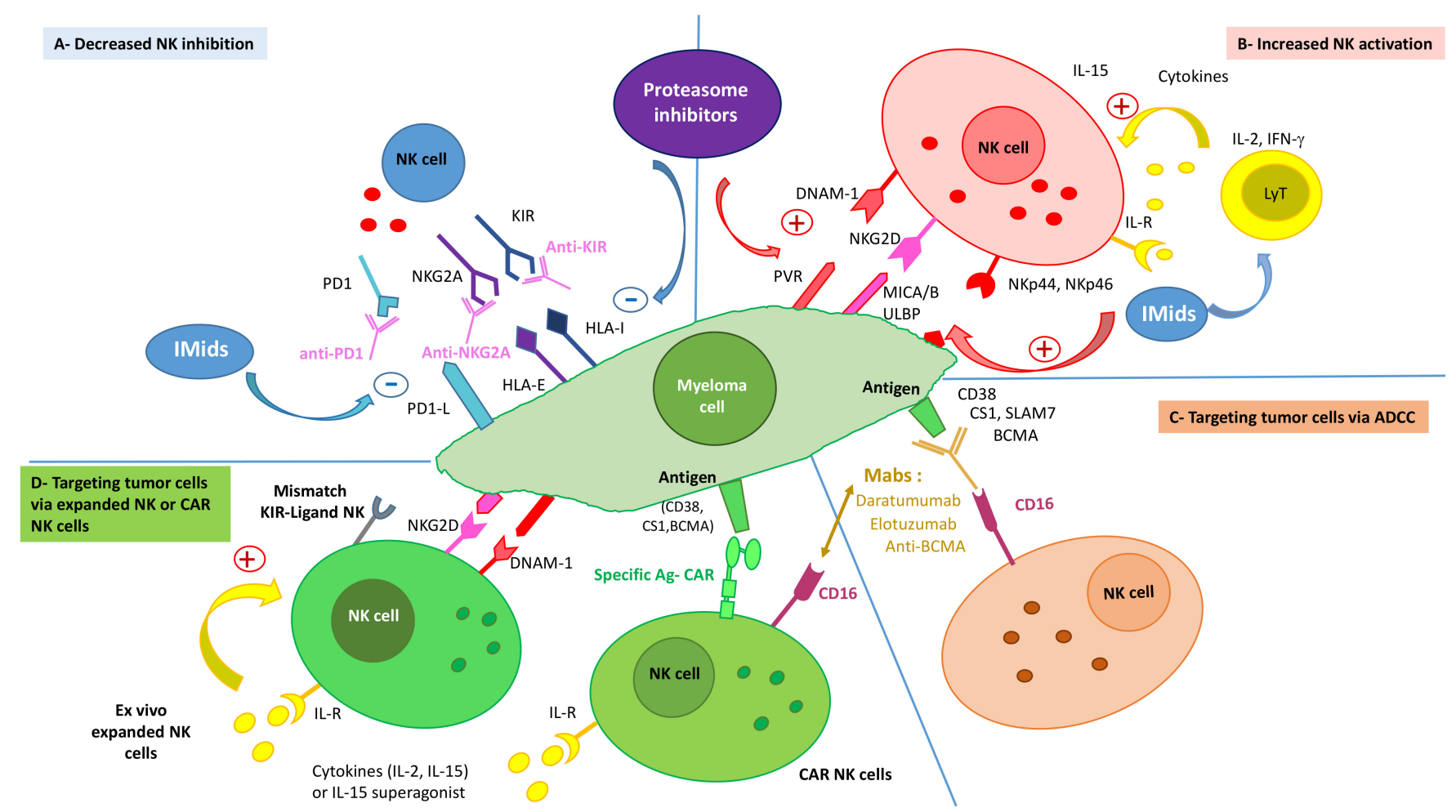

Figure 2. Restauration and enhancement of NK cell functions in multiple myeloma (MM). (A). Decreased inhibition of NK cells: the inhibitory signaling can be overrided by several ways: infusion of haploidentical NK cells (haplo) with a killer cell immunoglobulin-like receptors (KIR)-ligand mismatch, the use of anti-KIR, anti-NKG2A or anti-PD1 monoclonal antibodies (mAbs), or by reducing tumor cell surface expression of HLA-I by proteasome inhibitors (PI) or that of PDL-1 by immunomodulatory drugs (IMIDs) (B). Increased activation of NK cells: PIs and IMIDs can increase the tumor expression of ligands of activating receptors (polio virus receptor-PVR, MHC-related ligands (MICA), UL16-binding protein (ULBP)) and the corresponding receptors DNAX accessory molecule (DNAM-1) and NKG2D on NK cells. IMIDs or IL-15 can favor the activation and proliferation of NK cells (C). Targeting tumor cells via antibody-dependent cellular cytotoxicity (ADCC). CD16 (Fc-receptor) expressed on NK cells can bind to anti-CD38 (daratumumab), anti-CS1/SLAM7 (elotuzumab) or anti-BCMA mAbs and induce tumor killing by ADCC. (D). Targeting tumor cells via ex vivo expanded or chimeric antigen receptors (CAR) NK cells: Ex vivo expanded and activated NK cells expressing NK-activating receptors can kill tumor cells. CAR-NK cells can be engineered against various myeloma targets (see 2C). CD16 expressed on CAR NK cells can also mediate a synergistic effect in combination with antigen-specific mAbs.

\subsection{Modulation of NK Cells by Immunomodulatory Drugs and Monoclonal Abs}

Immunomodulatory drugs thalidomide, lenalidomide and pomalidomide stimulate the production of IL-2 and IFN- $\gamma$ by T cells, which, in turn, increases the proliferation of NK cells and their cytotoxicity against myeloma cells [60-62]. They increase the expression of NK-cell-activating ligands MICA, ULBP1 and PVR on myeloma cells and that of NK-activating receptors (NKG2D, NKp30, NKp46) on NK cells [62,63]. In addition, lenalidomide has been shown to enhance the expression of Fas-L and TRAIL on NK cells [61] while reducing PDL1 [38] on myeloma cells (Figure 2A,B). Importantly, the effects of IMids on NK cells are maintained when they are combined with a low dose of dexamethasone $[64,65]$.

Proteasome inhibitors bortezomib and carfilzomib also enhance NK-cell-mediated myeloma cell killing. Both downregulate the expression of HLA class I molecules on myeloma cells $[66,67]$, thus sensitizing them to NK cytotoxicity. In addition, bortezomib upregulates the expression of the ligands for NKG2D (MICA/MICB) and for DNAM-1 (PVR and nectin-2) on tumor cells $[68,69]$, and carfilzomib increases the expression of the CD107a thus the degranulation of NK cells [67] (Figure 2A,B). 
Through their expression of CD16 (FC $\gamma$ RIIIa), NK cells are recruited by monoclonal antibodies (mAbs) targeting tumor antigens and participate in tumor killing by antibodydependent cellular cytotoxicity (ADCC) [70] (Figure 2C). Daratumumab, a fully human IgG1, targets CD38, a transmembrane glycoprotein highly expressed on myeloma cells, but also on other hematopoietic cells, including NK cells [71]. Despite the associated killing of $\mathrm{CD}_{3} 8^{+/}$bright $\mathrm{NK}$ cells, daratumumab mediates its anti-MM effect via ADCC through remaining CD38 $8^{\text {neg/low }}$ NK cells, which have higher expansion and cytotoxicity capacities [71]. Elotuzumab is a humanized IgG1 directed against CS1/SLAM-7, a transmembrane glycoprotein highly expressed on myeloma cells and at lower levels on NK and CD8 T, NKT cells and activated monocytes [72]. Elotuzumab enhances NK-mediated myeloma cell killing by ADCC, but also by direct recognition of CS1 on NK cells. This latter induces the activation of NK cells through the signaling intermediate EAT2, which is not expressed on myeloma cells, inducing tumor cell lysis in complement to ADCC [73].

The combination of IMids or proteasome inhibitors to mAbs have shown synergistic effects on NK cell activation and ADCC induction in preclinical models as well as in clinical trials (lenalidomide or pomalidomide + elotuzumab, bortezomib or lenalidomide + daratumumab) [74-79].

\subsection{Expanded NK Cells for Cellular Immunotherapy in MM}

The anti-leukemic effects of NK cells in haplo-HSCT led to the development of NK cell therapies in several hematologic malignancies. Miller et al. reported that administration of activated HLA-haploidentical NK cells combined with in vivo subcutaneous injections of IL-2 after a lymphodepleting conditioning regimen (high-dose cyclophosphamide and fludarabine) resulted in an in vivo expansion of donor NK cells and the induction of anti-leukemic responses without GVHD in 5 out of 19 patients with poor-prognosis acute myeloid leukemia (AML), with higher responses in case of a KIR ligand-mismatched donor [80]. The same group demonstrated enhanced NK cell activity by concomitant depletion of Tregs by administration of IL-2-diphtheria fusion protein (IL-2DT) [81]. The potential curative or preventive effect of KIR ligand mismatched NK cell therapies in AML has been since reported by others $[82,83]$.

Because of the role of NK cells in the development of MM, the administration of activated NK cells represents an attractive therapeutic approach in this disease. Expansion of NK cells from PBMC of MM patients can be achieved in co-culture with feeder K562 cells transfected with CD137-L and IL-15, which activate and enhance the proliferation of highly cytotoxic NK cells expressing NKG2D and DNAM-1 [84] (Figure 2D). Such ex vivo expanded NK cells from myeloma patients have been infused in heavily pretreated patients with no serious adverse events, and responses lasting at least six months were observed in two out of seven patients [85]. In vitro expansion of PBMC-derived NK cells can also be performed in co-culture with polyvalent immunoglobulins, platelet lysate and lenalidomide, allowing an 80-fold expansion rated and the generation of highly cytotoxic and polyfunctional NK cells [86].

Administration of allogeneic KIR ligand-mismatched NK cells from haploidentical family donors was performed after conditioning regimen with melphalan and fludarabine in patients with advanced MM followed by delayed rescue with autologous stem cells. This approach led to short survival and in vivo expansion of donor NK cells but uncourageous response rates with $50 \%$ of near-complete remission [87]. A phase I study evaluated the safety and efficacy of sequential infusions of autologous ex vivo expanded NK cells in combination with lenalidomide or bortezomib-based treatments in 5 relapsed or refractory MM patients to 2 to 7 lines of treatment. After four cycles of treatment with $2 \mathrm{NK}$ cell infusions per cycle, four patients had stable disease, 2 showed a reduction in bone marrow plasma cell infiltration of $50 \%$, and one had a response lasting for more than a year [88]. Umbilical cord blood-derived NK cells have also been used in combination with autologous HSCT in 12 heavily pretreated and high cytogenetic risk MM [89]. An in vivo expansion 
of activated NKG2D ${ }^{+} / \mathrm{NKP} 30^{+}$NK cells was observed in 6 patients, and most patients achieved prolonged near $\mathrm{CR}(n=8)$ or very good partial response $(n=2)$.

IL-15 has the advantage over IL-2 to not support the maintenance of Tregs and to protect effector memory T cells as well. In a MM mouse model, the administration of the IL-15 superagonist ALT-803 increased T and NK-mediated-cell lysis of myeloma cells compared to conventional IL-15 [90,91]. In vitro-primed CD56 ${ }^{\text {bright }}$ NK cells by IL-15 have become more cytotoxic against myeloma cell lines, and a phase I study of administration of ALT-803 in MM patients showed a transient expansion of CD56 ${ }^{\text {bright }}$ NK cells in vivo with cytotoxic activity against U266 myeloma cell line [92]. A phase I study combining ALT-803 and expanded non-HLA matched allogeneic NK cells in hematologic malignancies, including MM, is ongoing (NCT02890758).

Overall, these studies suggest the therapeutic activity of NK cells for the treatment of MM when those are activated ex vivo and express activating KIRs or NCR to be able to overcome the high expression of HLA class I molecules on myeloma cells.

\subsection{CAR-NK in MM}

Genetic modifications of $\mathrm{T}$ cells with chimeric antigen receptors (CAR), first developed against CD19 for the treatment of lymphoid malignancies, have been explored in MM with different antigen targets (BCMA, CD38, CD138, SLMAF7, NKG2D, CD56) (reviewed in $[93,94])$. Among those, the most advanced are CAR-T cells recently targeting BCMA approved for the treatment of $\mathrm{R} / \mathrm{R} \mathrm{MM}$ patients [95]. With a median progression-free survival of 9 months, results of CAR-T cells in MM could be improved.

Compared to CAR-T cells, CAR-NK cells have several potential advantages [96] (i) they do not induce GVHD and can be safely used in an allogeneic setting, (ii) their shorter in vivo persistence in the allogeneic context and their mixed cytokine profile (both antiand proinflammatory and proapoptotic) may reduce cytokine release syndrome and other side effects, (iii) their expression of activating receptors may enhance their efficacy by nonCAR-dependent tumor lysis and (iv) their expression of CD16 could allow a synergistic effect in combination with monoclonal therapeutic antibodies. In addition, several sources of CAR-NK cells can be considered: primary NK cells, NK cell lines (NK-92), umbilical cord blood or induced pluripotent stem cells (iPSCs) [97]. CAR-NK cells are, therefore, under investigation in several hematologic malignancies. The most impressive results have been reported with cord blood-derived NK cells transduced with an anti-CD19 and IL15-containing CAR construct tested in 11 patients with refractory lymphoid malignancies in a phase I study [98]. Despite HLA mismatches between CAR-NK cells and patients, none of them developed CRS, neurotoxicity or GVHD. Eight patients (73\%) responded within the first month, including 7 CR $(64 \%)$, and NK-CAR cells were detectable for up to one year after administration independently of the administrated dose, possibly because of the persistent production of IL-15 included in the CAR construct $[98,99]$. The clinical efficacy of CAR-NK is difficult to assess as most patients received a consolidation therapy (lenalidomide, allogeneic HSCT, etc.), but those preliminary results are very encouraging.

In MM, CAR-NK cells targeting CD138, BCMA, NKG2D or CS1/SLAMF7 have been explored in preclinical studies [100-102] (Figure 2D). Jiang et al. demonstrated that NK-92 cells transduced with an anti-CD138 CAR kill myeloma cell lines and primary tumor plasma cells in vitro and that administration of irradiated CAR-NK-92 cells has strong antitumor activity towards CD138-positive MM cells in the xenograft NOD-SCID mouse model [100]. Chu et al. reported similar results with NK-92 cells expressing an antiCS1/SLAMF7 CAR [101]. Another group observed similar efficacy between anti-NKG2D and anti-BCMA NK cells in eradicating myeloma cells [102]. A phase I trial with antiBCMA CAR NK-92 cells for R/R myeloma patients is ongoing in China (NCT03940833). A combination of anti-CD38 monoclonal antibody daratumumab and anti-CS1 CAR CD38 $8^{\text {neg }}$ NK cells has been described to treat relapsed MM with the hypothesis of a synergistic effect of Daratumumab and CAR-CD38 ${ }^{\text {neg }}$ NK cells [103] (Figure 2D). 


\subsection{KIR and Check Point Inhibitors in MM}

Blocking NK cell inhibitory molecules by monoclonal antibodies represents another way to increase the efficacy of NK cells against tumor cells (Figure 2A).

The interest of targeting the PD1/PDL1 axis in MM was first described by Benson et al., who showed that the anti-PD1 antibody CT-011 could enhance NK cell function against primary myeloma cells expressing PDL-1, with a synergistic effect when combined with lenalidomide, which reduces PDL1 expression on myeloma cells [38]. In a preclinical model, the combination of anti-PD1 $\mathrm{mAb}$ and lenalidomide enhanced the effect of DC-based immunotherapy by inhibition of suppressive cells (MDSCs, Tregs and M2 macrophages) and activation of T and NK cytotoxic effector cells [104]. In humans, inhibition of the PD1/PDL1 axis with mAbs in monotherapy failed to demonstrate efficacy [105]. In combination with IMids, despite a good safety profile and some interesting responses observed in the first phase I-II studies evaluating the combination of pembrolizumab (antiPD-1) to lenalidomide or pomalidomide and dexamethasone [106-108], the unpredictable occurrence of immune-related adverse events reported in $\mathrm{R} / \mathrm{R}$ MM receiving a combination of anti-PD1 and IMids, conducted the FDA to discontinue all the trials exploring such combination of drugs [9]. Inhibition of the PD1/PDL1 axis is currently explored in R/R MM patients receiving anti-BCMA CAR T cells with a CAR also expressing a PD1-Fc fusion protein capable of inhibiting PD1/PDL1 (NCT04162119).

The KIR inhibitor mAb 1-7F9 was developed to inhibit different inhibitory KIRs (KIR2DL-1, -2 and -3) and enhance NK antitumor effect. This anti-KIR inhibitor $\mathrm{mAb}$ increases NK-cell-mediated killing of HLA-C expressing tumor cells in vitro and in vivo [109]. The combination of lenalidomide and IPH2101 (formerly 1-7F9) was shown to enhance NK cell-mediated anti-myeloma responses in a preclinical model [110]. IPH2101 was, therefore, tested in phase I and II trials in MM. The first phase I included 32 patients with R/R MM, who received up to four cycles of 28-day intravenous administration of IPH2101 at different doses demonstrated that the drug was well-tolerated, and the treatment was associated with the full saturation of inhibitory KIRs and anti-myeloma cell NK-mediated killing [111]. Another phase I study explored the combination of lenalidomide and IPH2101 in 15 MM patients and showed a response in 5 patients, but severe adverse events were observed in 5 patients [112]. However, in smoldering MM patients, IPH2101 failed to reach a 50\% decline of the M-protein [113]. Lirilumab, a recombinant version of IPH2101 that also recognizes the activating KIRs KIR2DS1 and -2, has been tested in combination with the anti-PD1 nivolumab in a phase I study in R/R lymphoid malignancies, but no objective response was observed in MM patients [114]. Actually, because of its inhibition of both inhibitory and activating KIRs, the effect of lirilumab will depend on MHC class I expression and KIR receptor repertoire. In addition, it has been reported that KIR2D molecules are removed from NK cells by monocyte trogocytosis under the pressure of IPH2101, a phenomenon associated with a reduction of NK cell cytotoxicity in vivo [115]. Altogether, these results suggest using anti-inhibitory KIRs in association with other immunomodulatory drugs rather than as a single-agent. Results of a phase analyzing the combination of elotuzumab with lirilumab or urelumab (anti-4-1BB mAb) in MM are pending (NCT02252263).

Monalizumab, a humanized mAb, was developed to block the heterodimer CD94/ NKG2A and reverse the inhibitory signaling induced by NKG2A on NK cells and HLA-E on tumor cells [116]. An ongoing phase I trial is investigating the safety of monalizumab in hematologic malignancies, including MM relapsing after allo-HSTC (NCT02921685).

\section{Conclusions}

Multiple myeloma is a multiple-step evoluting disease. During disease evolution, tumor cells escape to immune surveillance, particularly to NK cell control. Restoring NK cell cytotoxicity against myeloma tumor plasma cells is a major goal of MM treatment strategies. Conventional treatments (IMids, proteasome inhibitors and monoclonal antibodies) can modulate and enhance NK cell recognition and killing of myeloma plasma cells. NK cell-based therapies, such as expanded and activated KIR mismatched and partic- 
ularly CAR NK cells, are promising, as well as blocking NK cell inhibitory checkpoint and receptors. The actions of all these treatment approaches are complementary and synergistic. Future studies will help to define the best combination strategies and the respective place of conventional versus cellular and/or inhibitor blockers in the therapeutic care of multiple myeloma.

Author Contributions: M.T.R. wrote and reviewed the manuscript, A.D. and S.N.-Q. made figures and reviewed the manuscript. All authors have read and agreed to the published version of the manuscript.

Funding: This research received no external funding.

Institutional Review Board Statement: Not applicable.

Informed Consent Statement: Not applicable.

Data Availability Statement: Not applicable.

Conflicts of Interest: The authors declare no conflict of interest.

\section{References}

1. Raab, M.S.; Podar, K.; Breitkreutz, I.; Richardson, P.G.; Anderson, K.C. Multiple myeloma. Lancet 2009, 374, 324-339. [CrossRef]

2. Blade, J.; Rosinol, L.; Cibeira, M.T.; de Larrea, C.F. Pathogenesis and progression of monoclonal gammopathy of undetermined significance. Leukemia 2008, 22, 1651-1657. [CrossRef]

3. Kawano, Y.; Roccaro, A.M.; Ghobrial, I.M.; Azzi, J. Multiple Myeloma and the Immune Microenvironment. Curr. Cancer Drug Targets 2017, 17, 806-818. [CrossRef] [PubMed]

4. Dosani, T.; Carlsten, M.; Maric, I.; Landgren, O. The cellular immune system in myelomagenesis: NK cells and T cells in the development of myeloma [corrected] and their uses in immunotherapies. Blood Cancer J. 2015, 5, e306. [CrossRef] [PubMed]

5. Vivier, E.; Tomasello, E.; Baratin, M.; Walzer, T.; Ugolini, S. Functions of natural killer cells. Nat. Immunol. 2008, 9, 503-510. [CrossRef]

6. Campbell, K.S.; Hasegawa, J. Natural killer cell biology: An update and future directions. J. Allergy Clin. Immunol. 2013, 132, 536-544. [CrossRef]

7. Kumar, S. Natural killer cell cytotoxicity and its regulation by inhibitory receptors. Immunology 2018, 154, 383-393. [CrossRef]

8. Pegram, H.J.; Andrews, D.M.; Smyth, M.J.; Darcy, P.K.; Kershaw, M.H. Activating and inhibitory receptors of natural killer cells. Immunol. Cell Biol. 2011, 89, 216-224. [CrossRef]

9. Alfarra, H.; Weir, J.; Grieve, S.; Reiman, T. Targeting NK Cell Inhibitory Receptors for Precision Multiple Myeloma Immunotherapy. Front. Immunol. 2020, 11, 575609. [CrossRef] [PubMed]

10. Barrow, A.D.; Martin, C.J.; Colonna, M. The Natural Cytotoxicity Receptors in Health and Disease. Front. Immunol. 2019, 10, 909. [CrossRef]

11. Lupo, K.B.; Matosevic, S. Natural Killer Cells as Allogeneic Effectors in Adoptive Cancer Immunotherapy. Cancers 2019, 11, 769. [CrossRef]

12. Lin, W.; Voskens, C.J.; Zhang, X.; Schindler, D.G.; Wood, A.; Burch, E.; Wei, Y.; Chen, L.; Tian, G.; Tamada, K.; et al. Fc-dependent expression of CD137 on human NK cells: Insights into "agonistic" effects of anti-CD137 monoclonal antibodies. Blood 2008, 112, 699-707. [CrossRef] [PubMed]

13. Aversa, F.; Tabilio, A.; Velardi, A.; Cunningham, I.; Terenzi, A.; Falzetti, F.; Ruggeri, L.; Barbabietola, G.; Aristei, C.; Latini, P.; et al. Treatment of high-risk acute leukemia with T-cell-depleted stem cells from related donors with one fully mismatched HLA haplotype. N. Engl. J. Med. 1998, 339, 1186-1193. [CrossRef] [PubMed]

14. Ruggeri, L.; Capanni, M.; Casucci, M.; Volpi, I.; Tosti, A.; Perruccio, K.; Urbani, E.; Negrin, R.S.; Martelli, M.F.; Velardi, A. Role of natural killer cell alloreactivity in HLA-mismatched hematopoietic stem cell transplantation. Blood 1999, 94, 333-339. [CrossRef] [PubMed]

15. Ruggeri, L.; Capanni, M.; Urbani, E.; Perruccio, K.; Shlomchik, W.D.; Tosti, A.; Posati, S.; Rogaia, D.; Frassoni, F.; Aversa, F.; et al. Effectiveness of donor natural killer cell alloreactivity in mismatched hematopoietic transplants. Science 2002, 295, 2097-2100. [CrossRef]

16. Velardi, A.; Ruggeri, L.; Alessandro Moretta Moretta, L. NK cells: A lesson from mismatched hematopoietic transplantation. Trends Immunol. 2002, 23, 438-444. [CrossRef]

17. Aversa, F.; Terenzi, A.; Tabilio, A.; Falzetti, F.; Carotti, A.; Ballanti, S.; Felicini, R.; Falcinelli, F.; Velardi, A.; Ruggeri, L.; et al. Full haplotype-mismatched hematopoietic stem-cell transplantation: A phase II study in patients with acute leukemia at high risk of relapse. J. Clin. Oncol. 2005, 23, 3447-3454. [CrossRef] 
18. Pende, D.; Marcenaro, S.; Falco, M.; Martini, S.; Bernardo, M.E.; Montagna, D.; Romeo, E.; Cognet, C.; Martinetti, M.; Maccario, R.; et al. Anti-leukemia activity of alloreactive NK cells in KIR ligand-mismatched haploidentical HSCT for pediatric patients: Evaluation of the functional role of activating KIR and redefinition of inhibitory KIR specificity. Blood 2009, 113, 3119-3129. [CrossRef]

19. Locatelli, F.; Bauquet, A.; Palumbo, G.; Moretta, F.; Bertaina, A. Negative depletion of alpha/beta+ T cells and of CD19+ B lymphocytes: A novel frontier to optimize the effect of innate immunity in HLA-mismatched hematopoietic stem cell transplantation. Immunol. Lett. 2013, 155, 21-23. [CrossRef] [PubMed]

20. Kroger, N.; Shaw, B.; Iacobelli, S.; Zabelina, T.; Peggs, K.; Shimoni, A.; Nagler, A.; Binder, T.; Eiermann, T.; Madrigal, A.; et al. Comparison between antithymocyte globulin and alemtuzumab and the possible impact of KIR-ligand mismatch after dose-reduced conditioning and unrelated stem cell transplantation in patients with multiple myeloma. Br. J. Haematol. 2005, 129, 631-643. [CrossRef] [PubMed]

21. Davies, S.M.; Ruggieri, L.; DeFor, T.; Wagner, J.E.; Weisdorf, D.J.; Miller, J.S.; Velardi, A.; Blazar, B.R. Evaluation of KIR ligand incompatibility in mismatched unrelated donor hematopoietic transplants. Killer immunoglobulin-like receptor. Blood 2002, 100, 3825-3827. [CrossRef]

22. Farag, S.S.; Bacigalupo, A.; Eapen, M.; Hurley, C.; Dupont, B.; Caligiuri, M.A.; Boudreau, C.; Nelson, G.; Oudshoorn, M.; van Rood, J.; et al. The effect of KIR ligand incompatibility on the outcome of unrelated donor transplantation: A report from the center for international blood and marrow transplant research, the European blood and marrow transplant registry, and the Dutch registry. Biol. Blood Marrow Transplant. 2006, 12, 876-884. [CrossRef]

23. Brunstein, C.G.; Wagner, J.E.; Weisdorf, D.J.; Cooley, S.; Noreen, H.; Barker, J.N.; DeFor, T.; Verneris, M.R.; Blazar, B.R.; Miller, J.S. Negative effect of KIR alloreactivity in recipients of umbilical cord blood transplant depends on transplantation conditioning intensity. Blood 2009, 113, 5628-5634. [CrossRef]

24. Russo, A.; Oliveira, G.; Berglund, S.; Greco, R.; Gambacorta, V.; Cieri, N.; Toffalori, C.; Zito, L.; Lorentino, F.; Piemontese, S.; et al. NK cell recovery after haploidentical HSCT with posttransplant cyclophosphamide: Dynamics and clinical implications. Blood 2018, 131, 247-262. [CrossRef] [PubMed]

25. Nguyen, S.; Beziat, V.; Roos-Weil, D.; Vieillard, V. Role of natural killer cells in hematopoietic stem cell transplantation: Myth or reality? J. Innate. Immun. 2011, 3, 383-394. [CrossRef] [PubMed]

26. Cooley, S.; Trachtenberg, E.; Bergemann, T.L.; Saeteurn, K.; Klein, J.; Le, C.T.; Marsh, S.G.; Guethlein, L.A.; Parham, P.; Miller, J.S.; et al. Donors with group B KIR haplotypes improve relapse-free survival after unrelated hematopoietic cell transplantation for acute myelogenous leukemia. Blood 2009, 113, 726-732. [CrossRef] [PubMed]

27. Cooley, S.; Weisdorf, D.J.; Guethlein, L.A.; Klein, J.P.; Wang, T.; Le, C.T.; Marsh, S.G.; Geraghty, D.; Spellman, S.; Haagenson, M.D.; et al. Donor selection for natural killer cell receptor genes leads to superior survival after unrelated transplantation for acute myelogenous leukemia. Blood 2010, 116, 2411-2419. [CrossRef] [PubMed]

28. Venstrom, J.M.; Pittari, G.; Gooley, T.A.; Chewning, J.H.; Spellman, S.; Haagenson, M.; Gallagher, M.M.; Malkki, M.; Petersdorf, E.; Dupont, B.; et al. HLA-C-dependent prevention of leukemia relapse by donor activating KIR2DS1. N. Engl. J. Med. 2012, 367, 805-816. [CrossRef] [PubMed]

29. Nguyen, S.; Dhedin, N.; Vernant, J.P.; Kuentz, M.; Al Jijakli, A.; Rouas-Freiss, N.; Carosella, E.D.; Boudifa, A.; Debre, P.; Vieillard, V. NK-cell reconstitution after haploidentical hematopoietic stem-cell transplantations: Immaturity of NK cells and inhibitory effect of NKG2A override GvL effect. Blood 2005, 105, 4135-4142. [CrossRef] [PubMed]

30. Frohn, C.; Hoppner, M.; Schlenke, P.; Kirchner, H.; Koritke, P.; Luhm, J. Anti-myeloma activity of natural killer lymphocytes. Br. J. Haematol. 2002, 119, 660-664. [CrossRef] [PubMed]

31. Carbone, E.; Neri, P.; Mesuraca, M.; Fulciniti, M.T.; Otsuki, T.; Pende, D.; Groh, V.; Spies, T.; Pollio, G.; Cosman, D.; et al. HLA class I, NKG2D, and natural cytotoxicity receptors regulate multiple myeloma cell recognition by natural killer cells. Blood 2005, 105, 251-258. [CrossRef] [PubMed]

32. El-Sherbiny, Y.M.; Meade, J.L.; Holmes, T.D.; McGonagle, D.; Mackie, S.L.; Morgan, A.W.; Cook, G.; Feyler, S.; Richards, S.J.; Davies, F.E.; et al. The requirement for DNAM-1, NKG2D, and NKp46 in the natural killer cell-mediated killing of myeloma cells. Cancer Res. 2007, 67, 8444-8449. [CrossRef] [PubMed]

33. Tienhaara, A.; Pelliniemi, T.T. Peripheral blood lymphocyte subsets in multiple myeloma and monoclonal gammopathy of undetermined significance. Clin. Lab. Haematol. 1994, 16, 213-223. [CrossRef] [PubMed]

34. Famularo, G.; D’Ambrosio, A.; Quintieri, F.; Di Giovanni, S.; Parzanese, I.; Pizzuto, F.; Giacomelli, R.; Pugliese, O.; Tonietti, G. Natural killer cell frequency and function in patients with monoclonal gammopathies. J. Clin. Lab. Immunol. 1992, 37, 99-109. [PubMed]

35. Jurisic, V.; Srdic, T.; Konjevic, G.; Markovic, O.; Colovic, M. Clinical stage-depending decrease of NK cell activity in multiple myeloma patients. Med. Oncol. 2007, 24, 312-317. [CrossRef]

36. Fauriat, C.; Mallet, F.; Olive, D.; Costello, R.T. Impaired activating receptor expression pattern in natural killer cells from patients with multiple myeloma. Leukemia 2006, 20, 732-733. [CrossRef]

37. Costello, R.T.; Boehrer, A.; Sanchez, C.; Mercier, D.; Baier, C.; Le Treut, T.; Sebahoun, G. Differential expression of natural killer cell activating receptors in blood versus bone marrow in patients with monoclonal gammopathy. Immunology 2013, 139, 338-341. [CrossRef] 
38. Benson, D.M., Jr.; Bakan, C.E.; Mishra, A.; Hofmeister, C.C.; Efebera, Y.; Becknell, B.; Baiocchi, R.A.; Zhang, J.; Yu, J.; Smith, M.K.; et al. The PD-1/PD-L1 axis modulates the natural killer cell versus multiple myeloma effect: A therapeutic target for CT-011, a novel monoclonal anti-PD-1 antibody. Blood 2010, 116, 2286-2294. [CrossRef]

39. Konjevic, G.; Vuletic, A.; Mirjacic Martinovic, K.; Colovic, N.; Colovic, M.; Jurisic, V. Decreased CD161 activating and increased CD158a inhibitory receptor expression on NK cells underlies impaired NK cell cytotoxicity in patients with multiple myeloma. $J$. Clin. Pathol. 2016, 69, 1009-1016. [CrossRef]

40. Bhutani, M.; Foureau, D.; Zhang, Q.; Robinson, M.; Wynn, A.S.; Steuerwald, N.M.; Druhan, L.J.; Guo, F.; Rigby, K.; Turner, M.; et al. Peripheral Immunotype Correlates with Minimal Residual Disease Status and Is Modulated by Immunomodulatory Drugs in Multiple Myeloma. Biol. Blood Marrow Transplant. 2019, 25, 459-465. [CrossRef]

41. Bianchi, G.; Munshi, N.C. Pathogenesis beyond the cancer clone(s) in multiple myeloma. Blood 2015, 125, 3049-3058. [CrossRef] [PubMed]

42. Urashima, M.; Ogata, A.; Chauhan, D.; Hatziyanni, M.; Vidriales, M.B.; Dedera, D.A.; Schlossman, R.L.; Anderson, K.C. Transforming growth factor-beta1: Differential effects on multiple myeloma versus normal B cells. Blood 1996, 87, 1928-1938 [CrossRef]

43. Beyer, M.; Kochanek, M.; Giese, T.; Endl, E.; Weihrauch, M.R.; Knolle, P.A.; Classen, S.; Schultze, J.L. In vivo peripheral expansion of naive CD4+CD25high FoxP3+ regulatory T cells in patients with multiple myeloma. Blood 2006, 107, 3940-3949. [CrossRef]

44. Van Valckenborgh, E.; Schouppe, E.; Movahedi, K.; De Bruyne, E.; Menu, E.; De Baetselier, P.; Vanderkerken, K.; Van Ginderachter J.A. Multiple myeloma induces the immunosuppressive capacity of distinct myeloid-derived suppressor cell subpopulations in the bone marrow. Leukemia 2012, 26, 2424-2428. [CrossRef] [PubMed]

45. Li, H.; Han, Y.; Guo, Q.; Zhang, M.; Cao, X. Cancer-expanded myeloid-derived suppressor cells induce anergy of NK cells through membrane-bound TGF-beta 1. J. Immunol. 2009, 182, 240-249. [CrossRef] [PubMed]

46. Castriconi, R.; Cantoni, C.; Della Chiesa, M.; Vitale, M.; Marcenaro, E.; Conte, R.; Biassoni, R.; Bottino, C.; Moretta, L.; Moretta, A. Transforming growth factor beta 1 inhibits expression of NKp30 and NKG2D receptors: Consequences for the NK-mediated killing of dendritic cells. Proc. Natl. Acad. Sci. USA 2003, 100, 4120-4125. [CrossRef]

47. Sharma, A.; Khan, R.; Joshi, S.; Kumar, L.; Sharma, M. Dysregulation in T helper 1/T helper 2 cytokine ratios in patients with multiple myeloma. Leuk. Lymphoma 2010, 51, 920-927. [CrossRef] [PubMed]

48. Bataille, R.; Jourdan, M.; Zhang, X.G.; Klein, B. Serum levels of interleukin 6, a potent myeloma cell growth factor, as a reflect of disease severity in plasma cell dyscrasias. J. Clin. Investig. 1989, 84, 2008-2011. [CrossRef]

49. Tsuruma, T.; Yagihashi, A.; Hirata, K.; Torigoe, T.; Araya, J.; Watanabe, N.; Sato, N. Interleukin-10 reduces natural killer (NK) sensitivity of tumor cells by downregulating NK target structure expression. Cell. Immunol. 1999, 198, 103-110. [CrossRef]

50. Cifaldi, L.; Prencipe, G.; Caiello, I.; Bracaglia, C.; Locatelli, F.; De Benedetti, F.; Strippoli, R. Inhibition of natural killer cell cytotoxicity by interleukin-6: Implications for the pathogenesis of macrophage activation syndrome. Arthritis Rheumatol. 2015, 67, 3037-3046. [CrossRef]

51. Lu, Z.Y.; Bataille, R.; Poubelle, P.; Rapp, M.J.; Harousseau, J.L.; Klein, B. An interleukin 1 receptor antagonist blocks the IL-1induced IL-6 paracrine production through a prostaglandin E2-related mechanism in multiple myeloma. Stem Cells 1995, 13 (Suppl. S2), 28-34.

52. Martinet, L.; Jean, C.; Dietrich, G.; Fournie, J.J.; Poupot, R. PGE2 inhibits natural killer and gamma delta T cell cytotoxicity triggered by NKR and TCR through a cAMP-mediated PKA type I-dependent signaling. Biochem. Pharmacol. 2010, 80, 838-845. [CrossRef]

53. Nair, J.R.; Carlson, L.M.; Koorella, C.; Rozanski, C.H.; Byrne, G.E.; Bergsagel, P.L.; Shaughnessy, J.P., Jr.; Boise, L.H.; Chanan-Khan, A.; Lee, K.P. CD28 expressed on malignant plasma cells induces a prosurvival and immunosuppressive microenvironment. $J$. Immunol. 2011, 187, 1243-1253. [CrossRef]

54. Della Chiesa, M.; Carlomagno, S.; Frumento, G.; Balsamo, M.; Cantoni, C.; Conte, R.; Moretta, L.; Moretta, A.; Vitale, M. The tryptophan catabolite L-kynurenine inhibits the surface expression of NKp46- and NKG2D-activating receptors and regulates NK-cell function. Blood 2006, 108, 4118-4125. [CrossRef]

55. Sarkar, S.; van Gelder, M.; Noort, W.; Xu, Y.; Rouschop, K.M.; Groen, R.; Schouten, H.C.; Tilanus, M.G.; Germeraad, W.T.; Martens, A.C.; et al. Optimal selection of natural killer cells to kill myeloma: The role of HLA-E and NKG2A. Cancer Immunol. Immunother. 2015, 64, 951-963. [CrossRef] [PubMed]

56. Jinushi, M.; Vanneman, M.; Munshi, N.C.; Tai, Y.T.; Prabhala, R.H.; Ritz, J.; Neuberg, D.; Anderson, K.C.; Carrasco, D.R.; Dranoff, G. MHC class I chain-related protein A antibodies and shedding are associated with the progression of multiple myeloma. Proc. Natl. Acad. Sci. USA 2008, 105, 1285-1290. [CrossRef]

57. Groh, V.; Wu, J.; Yee, C.; Spies, T. Tumour-derived soluble MIC ligands impair expression of NKG2D and T-cell activation. Nature 2002, 419, 734-738. [CrossRef] [PubMed]

58. Xiao, G.; Wang, X.; Sheng, J.; Lu, S.; Yu, X.; Wu, J.D. Soluble NKG2D ligand promotes MDSC expansion and skews macrophage to the alternatively activated phenotype. J. Hematol. Oncol. 2015, 8, 13. [CrossRef] [PubMed]

59. Ponzetta, A.; Benigni, G.; Antonangeli, F.; Sciume, G.; Sanseviero, E.; Zingoni, A.; Ricciardi, M.R.; Petrucci, M.T.; Santoni, A.; Bernardini, G. Multiple Myeloma Impairs Bone Marrow Localization of Effector Natural Killer Cells by Altering the Chemokine Microenvironment. Cancer Res. 2015, 75, 4766-4777. [CrossRef] 
60. Davies, F.E.; Raje, N.; Hideshima, T.; Lentzsch, S.; Young, G.; Tai, Y.T.; Lin, B.; Podar, K.; Gupta, D.; Chauhan, D.; et al. Thalidomide and immunomodulatory derivatives augment natural killer cell cytotoxicity in multiple myeloma. Blood 2001, 98, 210-216. [CrossRef] [PubMed]

61. Quach, H.; Ritchie, D.; Stewart, A.K.; Neeson, P.; Harrison, S.; Smyth, M.J.; Prince, H.M. Mechanism of action of immunomodulatory drugs (IMiDS) in multiple myeloma. Leukemia 2010, 24, 22-32. [CrossRef]

62. Hayashi, T.; Hideshima, T.; Akiyama, M.; Podar, K.; Yasui, H.; Raje, N.; Kumar, S.; Chauhan, D.; Treon, S.P.; Richardson, P.; et al. Molecular mechanisms whereby immunomodulatory drugs activate natural killer cells: Clinical application. Br. J. Haematol. 2005, 128, 192-203. [CrossRef]

63. Lagrue, K.; Carisey, A.; Morgan, D.J.; Chopra, R.; Davis, D.M. Lenalidomide augments actin remodeling and lowers NK-cell activation thresholds. Blood 2015, 126, 50-60. [CrossRef]

64. Sehgal, K.; Das, R.; Zhang, L.; Verma, R.; Deng, Y.; Kocoglu, M.; Vasquez, J.; Koduru, S.; Ren, Y.; Wang, M.; et al. Clinical and pharmacodynamic analysis of pomalidomide dosing strategies in myeloma: Impact of immune activation and cereblon targets. Blood 2015, 125, 4042-4051. [CrossRef]

65. Paiva, B.; Mateos, M.V.; Sanchez-Abarca, L.I.; Puig, N.; Vidriales, M.B.; Lopez-Corral, L.; Corchete, L.A.; Hernandez, M.T.; Bargay, J.; de Arriba, F.; et al. Immune status of high-risk smoldering multiple myeloma patients and its therapeutic modulation under LenDex: A longitudinal analysis. Blood 2016, 127, 1151-1162. [CrossRef] [PubMed]

66. Shi, J.; Tricot, G.J.; Garg, T.K.; Malaviarachchi, P.A.; Szmania, S.M.; Kellum, R.E.; Storrie, B.; Mulder, A.; Shaughnessy, J.D., Jr.; Barlogie, B.; et al. Bortezomib down-regulates the cell-surface expression of HLA class I and enhances natural killer cell-mediated lysis of myeloma. Blood 2008, 111, 1309-1317. [CrossRef]

67. Yang, G.; Gao, M.; Zhang, Y.; Kong, Y.; Gao, L.; Tao, Y.; Han, Y.; Wu, H.; Meng, X.; Xu, H.; et al. Carfilzomib enhances natural killer cell-mediated lysis of myeloma linked with decreasing expression of HLA class I. Oncotarget 2015, 6, 26982-26994. [CrossRef] [PubMed]

68. Niu, C.; Jin, H.; Li, M.; Zhu, S.; Zhou, L.; Jin, F.; Zhou, Y.; Xu, D.; Xu, J.; Zhao, L.; et al. Low-dose bortezomib increases the expression of NKG2D and DNAM-1 ligands and enhances induced NK and gammadelta T cell-mediated lysis in multiple myeloma. Oncotarget 2017, 8, 5954-5964. [CrossRef] [PubMed]

69. Soriani, A.; Zingoni, A.; Cerboni, C.; Iannitto, M.L.; Ricciardi, M.R.; Di Gialleonardo, V.; Cippitelli, M.; Fionda, C.; Petrucci, M.T.; Guarini, A.; et al. ATM-ATR-dependent up-regulation of DNAM-1 and NKG2D ligands on multiple myeloma cells by therapeutic agents results in enhanced NK-cell susceptibility and is associated with a senescent phenotype. Blood 2009, 113, 3503-3511. [CrossRef]

70. Wang, W.; Erbe, A.K.; Hank, J.A.; Morris, Z.S.; Sondel, P.M. NK Cell-Mediated Antibody-Dependent Cellular Cytotoxicity in Cancer Immunotherapy. Front. Immunol. 2015, 6, 368. [CrossRef] [PubMed]

71. Wang, Y.; Zhang, Y.; Hughes, T.; Zhang, J.; Caligiuri, M.A.; Benson, D.M.; Yu, J. Fratricide of NK Cells in Daratumumab Therapy for Multiple Myeloma Overcome by Ex Vivo-Expanded Autologous NK Cells. Clin. Cancer Res. 2018, 24, 4006-4017. [CrossRef]

72. Ritchie, D.; Colonna, M. Mechanisms of Action and Clinical Development of Elotuzumab. Clin. Transl. Sci. 2018, 11, 261-266. [CrossRef]

73. Collins, S.M.; Bakan, C.E.; Swartzel, G.D.; Hofmeister, C.C.; Efebera, Y.A.; Kwon, H.; Starling, G.C.; Ciarlariello, D.; Bhaskar, S.; Briercheck, E.L.; et al. Elotuzumab directly enhances NK cell cytotoxicity against myeloma via CS1 ligation: Evidence for augmented NK cell function complementing ADCC. Cancer Immunol. Immunother. 2013, 62, 1841-1849. [CrossRef] [PubMed]

74. Nijhof, I.S.; Groen, R.W.; Noort, W.A.; van Kessel, B.; de Jong-Korlaar, R.; Bakker, J.; van Bueren, J.J.; Parren, P.W.; Lokhorst, H.M.; van de Donk, N.W.; et al. Preclinical Evidence for the Therapeutic Potential of CD38-Targeted Immuno-Chemotherapy in Multiple Myeloma Patients Refractory to Lenalidomide and Bortezomib. Clin. Cancer Res. 2015, 21, 2802-2810. [CrossRef] [PubMed]

75. Van der Veer, M.S.; de Weers, M.; van Kessel, B.; Bakker, J.M.; Wittebol, S.; Parren, P.W.; Lokhorst, H.M.; Mutis, T. Towards effective immunotherapy of myeloma: Enhanced elimination of myeloma cells by combination of lenalidomide with the human CD38 monoclonal antibody daratumumab. Haematologica 2011, 96, 284-290. [CrossRef] [PubMed]

76. Dimopoulos, M.A.; Lonial, S.; Betts, K.A.; Chen, C.; Zichlin, M.L.; Brun, A.; Signorovitch, J.E.; Makenbaeva, D.; Mekan, S.; Sy, O.; et al. Elotuzumab plus lenalidomide and dexamethasone in relapsed/refractory multiple myeloma: Extended 4-year follow-up and analysis of relative progression-free survival from the randomized ELOQUENT-2 trial. Cancer 2018, 124, $4032-4043$. [CrossRef]

77. Dimopoulos, M.A.; Dytfeld, D.; Grosicki, S.; Moreau, P.; Takezako, N.; Hori, M.; Leleu, X.; LeBlanc, R.; Suzuki, K.; Raab, M.S.; et al. Elotuzumab plus Pomalidomide and Dexamethasone for Multiple Myeloma. N. Engl. J. Med. 2018, 379, 1811-1822. [CrossRef]

78. Dimopoulos, M.A.; Oriol, A.; Nahi, H.; San-Miguel, J.; Bahlis, N.J.; Usmani, S.Z.; Rabin, N.; Orlowski, R.Z.; Komarnicki, M.; Suzuki, K.; et al. Daratumumab, Lenalidomide, and Dexamethasone for Multiple Myeloma. N. Engl. J. Med. 2016, 375, 1319-1331. [CrossRef]

79. Palumbo, A.; Chanan-Khan, A.; Weisel, K.; Nooka, A.K.; Masszi, T.; Beksac, M.; Spicka, I.; Hungria, V.; Munder, M.; Mateos, M.V.; et al. Daratumumab, Bortezomib, and Dexamethasone for Multiple Myeloma. N. Engl. J. Med. 2016, 375, 754-766. [CrossRef] [PubMed] 
80. Miller, J.S.; Soignier, Y.; Panoskaltsis-Mortari, A.; McNearney, S.A.; Yun, G.H.; Fautsch, S.K.; McKenna, D.; Le, C.; Defor, T.E.; Burns, L.J.; et al. Successful adoptive transfer and in vivo expansion of human haploidentical NK cells in patients with cancer. Blood 2005, 105, 3051-3057. [CrossRef]

81. Bachanova, V.; Cooley, S.; Defor, T.E.; Verneris, M.R.; Zhang, B.; McKenna, D.H.; Curtsinger, J.; Panoskaltsis-Mortari, A.; Lewis, D.; Hippen, K.; et al. Clearance of acute myeloid leukemia by haploidentical natural killer cells is improved using IL-2 diphtheria toxin fusion protein. Blood 2014, 123, 3855-3863. [CrossRef] [PubMed]

82. Rubnitz, J.E.; Inaba, H.; Ribeiro, R.C.; Pounds, S.; Rooney, B.; Bell, T.; Pui, C.H.; Leung, W. NKAML: A pilot study to determine the safety and feasibility of haploidentical natural killer cell transplantation in childhood acute myeloid leukemia. J. Clin. Oncol. 2010, 28, 955-959. [CrossRef] [PubMed]

83. Curti, A.; Ruggeri, L.; D'Addio, A.; Bontadini, A.; Dan, E.; Motta, M.R.; Trabanelli, S.; Giudice, V.; Urbani, E.; Martinelli, G.; et al. Successful transfer of alloreactive haploidentical KIR ligand-mismatched natural killer cells after infusion in elderly high risk acute myeloid leukemia patients. Blood 2011, 118, 3273-3279. [CrossRef] [PubMed]

84. Garg, T.K.; Szmania, S.M.; Khan, J.A.; Hoering, A.; Malbrough, P.A.; Moreno-Bost, A.; Greenway, A.D.; Lingo, J.D.; Li, X.; Yaccoby, S.; et al. Highly activated and expanded natural killer cells for multiple myeloma immunotherapy. Haematologica 2012, 97, 1348-1356. [CrossRef]

85. Szmania, S.; Lapteva, N.; Garg, T.; Greenway, A.; Lingo, J.; Nair, B.; Stone, K.; Woods, E.; Khan, J.; Stivers, J.; et al. Ex vivo-expanded natural killer cells demonstrate robust proliferation in vivo in high-risk relapsed multiple myeloma patients. $J$. Immunother. 2015, 38, 24-36. [CrossRef]

86. Trebeden-Negre, H.; Vieillard, V.; Rosenzwajg, M.; Garderet, L.; Cherai, M.; Nguyen-Quoc, S.; Tanguy, M.L.; Norol, F. Polyvalent immunoglobulins, platelet lysate and lenalidomide: Cocktail for polyfunctional NK cells expansion for multiple myeloma. Bone Marrow Transplant. 2017, 52, 480-483. [CrossRef]

87. Shi, J.; Tricot, G.; Szmania, S.; Rosen, N.; Garg, T.K.; Malaviarachchi, P.A.; Moreno, A.; Dupont, B.; Hsu, K.C.; Baxter-Lowe, L.A.; et al. Infusion of haplo-identical killer immunoglobulin-like receptor ligand mismatched NK cells for relapsed myeloma in the setting of autologous stem cell transplantation. Br. J. Haematol. 2008, 143, 641-653. [CrossRef]

88. Leivas, A.; Perez-Martinez, A.; Blanchard, M.J.; Martin-Clavero, E.; Fernandez, L.; Lahuerta, J.J.; Martinez-Lopez, J. Novel treatment strategy with autologous activated and expanded natural killer cells plus anti-myeloma drugs for multiple myeloma. Oncoimmunology 2016, 5, e1250051. [CrossRef]

89. Shah, N.; Li, L.; McCarty, J.; Kaur, I.; Yvon, E.; Shaim, H.; Muftuoglu, M.; Liu, E.; Orlowski, R.Z.; Cooper, L.; et al. Phase I study of cord blood-derived natural killer cells combined with autologous stem cell transplantation in multiple myeloma. Br. J. Haematol. 2017, 177, 457-466. [CrossRef]

90. Xu, W.; Jones, M.; Liu, B.; Zhu, X.; Johnson, C.B.; Edwards, A.C.; Kong, L.; Jeng, E.K.; Han, K.; Marcus, W.D.; et al. Efficacy and mechanism-of-action of a novel superagonist interleukin-15: Interleukin-15 receptor alphaSu/Fc fusion complex in syngeneic murine models of multiple myeloma. Cancer Res. 2013, 73, 3075-3086. [CrossRef]

91. Wong, H.C.; Jeng, E.K.; Rhode, P.R. The IL-15-based superagonist ALT-803 promotes the antigen-independent conversion of memory CD8(+) T cells into innate-like effector cells with antitumor activity. Oncoimmunology 2013, 2, e26442. [CrossRef] [PubMed]

92. Wagner, J.A.; Rosario, M.; Romee, R.; Berrien-Elliott, M.M.; Schneider, S.E.; Leong, J.W.; Sullivan, R.P.; Jewell, B.A.; Becker-Hapak, M.; Schappe, T.; et al. CD56bright NK cells exhibit potent antitumor responses following IL-15 priming. J. Clin. Investig. 2017, 127, 4042-4058. [CrossRef] [PubMed]

93. Kriegsmann, K.; Kriegsmann, M.; Cremer, M.; Schmitt, M.; Dreger, P.; Goldschmidt, H.; Muller-Tidow, C.; Hundemer, M. Cell-based immunotherapy approaches for multiple myeloma. Br. J. Cancer 2019, 120, 38-44. [CrossRef] [PubMed]

94. Shah, U.A.; Mailankody, S. CAR T and CAR NK cells in multiple myeloma: Expanding the targets. Best Pract. Res. Clin. Haematol. 2020, 33, 101141. [CrossRef] [PubMed]

95. Raje, N.; Berdeja, J.; Lin, Y.; Siegel, D.; Jagannath, S.; Madduri, D.; Liedtke, M.; Rosenblatt, J.; Maus, M.V.; Turka, A.; et al. Anti-BCMA CAR T-Cell Therapy bb2121 in Relapsed or Refractory Multiple Myeloma. N. Engl. J. Med. 2019, 380, $1726-1737$. [CrossRef] [PubMed]

96. Kloess, S.; Oberschmidt, O.; Dahlke, J.; Vu, X.K.; Neudoerfl, C.; Kloos, A.; Gardlowski, T.; Matthies, N.; Heuser, M.; Meyer, J.; et al. Preclinical Assessment of Suitable Natural Killer Cell Sources for Chimeric Antigen Receptor Natural Killer-Based "Off-the-Shelf" Acute Myeloid Leukemia Immunotherapies. Hum. Gene Ther. 2019, 30, 381-401. [CrossRef]

97. Rezvani, K. Adoptive cell therapy using engineered natural killer cells. Bone Marrow Transplant. 2019, 54 (Suppl. S2), 785-788. [CrossRef]

98. Liu, E.; Marin, D.; Banerjee, P.; Macapinlac, H.A.; Thompson, P.; Basar, R.; Nassif Kerbauy, L.; Overman, B.; Thall, P.; Kaplan, M.; et al. Use of CAR-Transduced Natural Killer Cells in CD19-Positive Lymphoid Tumors. N. Engl. J. Med. 2020, 382, 545-553. [CrossRef]

99. Liu, E.; Tong, Y.; Dotti, G.; Shaim, H.; Savoldo, B.; Mukherjee, M.; Orange, J.; Wan, X.; Lu, X.; Reynolds, A.; et al. Cord blood NK cells engineered to express IL-15 and a CD19-targeted CAR show long-term persistence and potent antitumor activity. Leukemia 2018, 32, 520-531. [CrossRef] 
100. Jiang, H.; Zhang, W.; Shang, P.; Zhang, H.; Fu, W.; Ye, F.; Zeng, T.; Huang, H.; Zhang, X.; Sun, W.; et al. Transfection of chimeric anti-CD138 gene enhances natural killer cell activation and killing of multiple myeloma cells. Mol. Oncol. 2014, 8, 297-310. [CrossRef]

101. Chu, J.; Deng, Y.; Benson, D.M.; He, S.; Hughes, T.; Zhang, J.; Peng, Y.; Mao, H.; Yi, L.; Ghoshal, K.; et al. CS1-specific chimeric antigen receptor (CAR)-engineered natural killer cells enhance in vitro and in vivo antitumor activity against human multiple myeloma. Leukemia 2014, 28, 917-927. [CrossRef] [PubMed]

102. Maroto-Martin, E.E.J.; Garcia-Ortiz, A.; Alonso, R.; Leivas, A.; Paciello, M.L. NKG2D and BCMA-CAR NK cells efficiently eliminate multiple myeloma cells. A comprehensive comparison between two clinically relevant CARs. HemaSphere 2019, 3 , 550-551. [CrossRef]

103. Wang, Y.; Zhang, Y.; Bnson, D.; Caligiuri, M.; Yu, J. Daratumumab combined with CD38(-) natural killer cells armed with a CS1 chimeric antigen receptor for the treatment of relapsed multiple myeloma. [abstract 4617]. In Proceedings of the American Association for Cancer Research, Washington, DC, USA, 1-5 April 2017; Volume 77.

104. Vo, M.C.; Jung, S.H.; Chu, T.H.; Lee, H.J.; Lakshmi, T.J.; Park, H.S.; Kim, H.J.; Rhee, J.H.; Lee, J.J. Lenalidomide and Programmed Death-1 Blockade Synergistically Enhances the Effects of Dendritic Cell Vaccination in a Model of Murine Myeloma. Front. Immunol. 2018, 9, 1370. [CrossRef] [PubMed]

105. Jelinek, T.; Paiva, B.; Hajek, R. Update on PD-1/PD-L1 Inhibitors in Multiple Myeloma. Front. Immunol. 2018, 9, 2431. [CrossRef] [PubMed]

106. Badros, A.Z.; Ma, N.; Rapoport, A.P.; Lederer, E.; Lesokhin, A.M. Long-term remissions after stopping pembrolizumab for relapsed or refractory multiple myeloma. Blood Adv. 2019, 3, 1658-1660. [CrossRef]

107. Mateos, M.V.; Orlowski, R.Z.; Ocio, E.M.; Rodriguez-Otero, P.; Reece, D.; Moreau, P.; Munshi, N.; Avigan, D.E.; Siegel, D.S.; Ghori, R.; et al. Pembrolizumab combined with lenalidomide and low-dose dexamethasone for relapsed or refractory multiple myeloma: Phase I KEYNOTE-023 study. Br. J. Haematol. 2019, 186, e117-e121. [CrossRef]

108. D’Souza, A.; Hari, P.; Pasquini, M.; Braun, T.; Johnson, B.; Lundy, S.; Couriel, D.; Hamadani, M.; Magenau, J.; Dhakal, B.; et al. A Phase 2 Study of Pembrolizumab during Lymphodepletion after Autologous Hematopoietic Cell Transplantation for Multiple Myeloma. Biol. Blood Marrow Transplant. 2019, 25, 1492-1497. [CrossRef]

109. Romagne, F.; Andre, P.; Spee, P.; Zahn, S.; Anfossi, N.; Gauthier, L.; Capanni, M.; Ruggeri, L.; Benson, D.M., Jr.; Blaser, B.W.; et al. Preclinical characterization of 1-7F9, a novel human anti-KIR receptor therapeutic antibody that augments natural killer-mediated killing of tumor cells. Blood 2009, 114, 2667-2677. [CrossRef]

110. Benson, D.M., Jr.; Bakan, C.E.; Zhang, S.; Collins, S.M.; Liang, J.; Srivastava, S.; Hofmeister, C.C.; Efebera, Y.; Andre, P.; Romagne, F.; et al. IPH2101, a novel anti-inhibitory KIR antibody, and lenalidomide combine to enhance the natural killer cell versus multiple myeloma effect. Blood 2011, 118, 6387-6391. [CrossRef]

111. Benson, D.M., Jr.; Hofmeister, C.C.; Padmanabhan, S.; Suvannasankha, A.; Jagannath, S.; Abonour, R.; Bakan, C.; Andre, P.; Efebera, Y.; Tiollier, J.; et al. A phase 1 trial of the anti-KIR antibody IPH2101 in patients with relapsed/refractory multiple myeloma. Blood 2012, 120, 4324-4333. [CrossRef]

112. Benson, D.M., Jr.; Cohen, A.D.; Jagannath, S.; Munshi, N.C.; Spitzer, G.; Hofmeister, C.C.; Efebera, Y.A.; Andre, P.; Zerbib, R.; Caligiuri, M.A. A Phase I Trial of the Anti-KIR Antibody IPH2101 and Lenalidomide in Patients with Relapsed/Refractory Multiple Myeloma. Clin. Cancer Res. 2015, 21, 4055-4061. [CrossRef] [PubMed]

113. Korde, N.; Carlsten, M.; Lee, M.J.; Minter, A.; Tan, E.; Kwok, M.; Manasanch, E.; Bhutani, M.; Tageja, N.; Roschewski, M.; et al. A phase II trial of pan-KIR2D blockade with IPH2101 in smoldering multiple myeloma. Haematologica 2014, 99, e81-e83. [CrossRef] [PubMed]

114. Armand, P.; Lesokhin, A.; Borrello, I.; Timmerman, J.; Gutierrez, M.; Zhu, L.; Popa McKiver, M.; Ansell, S.M. A phase 1b study of dual PD-1 and CTLA-4 or KIR blockade in patients with relapsed/refractory lymphoid malignancies. Leukemia 2020, 35, 777-786. [CrossRef] [PubMed]

115. Carlsten, M.; Korde, N.; Kotecha, R.; Reger, R.; Bor, S.; Kazandjian, D.; Landgren, O.; Childs, R.W. Checkpoint Inhibition of KIR2D with the Monoclonal Antibody IPH2101 Induces Contraction and Hyporesponsiveness of NK Cells in Patients with Myeloma. Clin. Cancer Res. 2016, 22, 5211-5222. [CrossRef]

116. Andre, P.; Denis, C.; Soulas, C.; Bourbon-Caillet, C.; Lopez, J.; Arnoux, T.; Blery, M.; Bonnafous, C.; Gauthier, L.; Morel, A.; et al. Anti-NKG2A mAb Is a Checkpoint Inhibitor that Promotes Anti-tumor Immunity by Unleashing Both T and NK Cells. Cell 2018, 175, 1731-1743. [CrossRef] 